\title{
Morphology of the Legend of Folklore on Unruly Daughter in West Sumatra's Minangkabau
}

\author{
Hasanuddin $\mathrm{WS}^{1, *}$, Emidar $^{1}$, Zulfadhli $^{1}$ \\ ${ }^{1}$ Indonesia Language and Literature Department, FBS Universitas Negeri Padang, Padang, Sumatra Barat 25131, \\ Indonesia \\ ${ }^{*}$ Corresponding author.Email: hasanuddinws@gmail.com; hasanuddinws@pps.unp.ac.id
}

\begin{abstract}
This article aims to discussion about the morphology of the legends folktale of the Minangkabau daughters in West Sumatra who was rebellious to her mother. This research is a descriptive qualitative study. The sources of data in this study are legendary folktales (1) Batu Puti Bayang (2) Awang Tingkuluak, (3) Batu Manangih, and (4) Batu Bangkai, represents the coastal area and mainland area of West Sumatra. Based on the research findings, the motifs of legends folktale is (1) Initial situation: (a) living as an only child, (b) living only with mother, (c) living in the situation is very simple/poor, (d) lazy and hedonist; (2) Transformation Situation: (e) likes to visit crowded places (including markets), (f) likes to preen, (g) does not like doing housework, (h) imposes domestic work on her mother; (3) Final situation: (i) with her mother going to the market, (j) refusing to acknowledge her mother to others because her mother is poor, (k) being cursed by her mother because she feels harassed as a maid; (l) changed to stone due to the mother's curse.
\end{abstract}

Keywords: morphology, functional structure, legendary folktale, rebllious girls, people Minangkabau, West Sumatra

\section{INTRODUCTION}

The Indonesian nation from a cultural perspective is a nation that has a strong culture that was formed over a very long period of time. This fact cannot be denied because there is evidence in the form of very valuable old relics that can still be found. Relics that prove the level of civilization of the Indonesian nation are not only in material form, such as temple buildings, inscriptions, ornaments in traditional houses or rice barns, tools for everyday life, but also in the form of relics. which is moral-spiritual. From cultural heritage that is moral-spiritual in nature, valuable information is obtained about concepts and patterns of thought, patterns of behavior, customs, systems of worship and belief, education and cultural traditions, as well as other things from the life of the ancestors of the Indonesian nation.

Cultural heritage in the form of moral-spiritual inheritance or also known as intangible cultural heritage, one of which is obtained and known through the oral tradition of folklore that lives in a society. Folklore is a part of culture that must be preserved through research and dissemination of information to the next generation. The folklore of the Minangkabau area has cultural values that can be continuously developed through research.

The issue that must be considered is the extent to which various forms of oral tradition as part of the developing culture in society have a function in fulfilling the social functions of people's lives. Thus, people believe in traditional values as truth and what they believe can lead to collective community solidarity (communal). Such beliefs can serve as inherited provisions and as knowledge. In addition, these beliefs can also function as arguments, hereditary practices, forms of memory, and beliefs about a decision.

In various situations, traditional values play a role in helping the dynamics and problems of community life where these fundamental values live and develop; creates solidarity among community members, fosters and develops community integrity, fosters community and collective pride in group identities, and is also useful for strengthening communal harmony. Thus, every society in essence, both traditional and modern society, needs life values that are based on certain beliefs or beliefs in order to live in harmony together.

From the nature and form of this nature, two Minangkabau traditional leaders, Datuak Parpatih Nan Sabatang and Datuak Katumanggungan, have formulated the people's lifestyle. Alam Minangkabau is divided into two areas, namely (1) the darek area (land; mountains) as the main supporting area for Minangkabau customs consisting of Luhak Agam, Luhak Tanah Datar, and Luhak Limo Puluah Koto; the darek region is considered to be the original area and origin where the Minangkabau people originated; and (2) rantau (coastal; supporting) areas, namely areas 
outside the three luhak. The Darek area as the main and relatively inland area is the base for the guardian of Minangkabau customs. Rantau area is an area that borders and intersects with the cultures of other communities, of course, the issue of influence and integration is an inevitable part.

In the case of folklore that is present in the form of folklore, the legends of the Minangkabau people in these two regions, which are administratively located in the province of West Sumatra, are interesting and important things to study.

Folklore is a story that is spoken orally in the mother tongue. Folklore can usually be categorized into myths, fairytale, and legend folktale. Legend folktale is the type of folklore that is most widely produced by the oral tradition community.

The object of this research is the folklore (1) Batu Puti Bayang, (2) Awang Tingkuluak, (3) Batu Manangih, and (4) Batu Bangkai. The selection of the four Minangkabu folk tales is based on the representation of the story with the background story of the coastal area of West Sumatra (coast), and the background story of the land area (mountains). The folklore of Batu Puti Bayang and Awang Tingkuluak is based on the story of the coastal areas (Pesisir Selatan Regency and Padangpariaman Regency), while the folklore of Batu Manangih and Batu Bangkai (Payakumbuh City and South Solok Regency) is set in a mountainous area.

The fourth study of local legend folk tales is focused on structural studies, especially the morphology of the stories and structural functionalities.

\section{METHODS}

This research is a qualitative research. The data in this study are the morphology of the legend of the Minagkabau girl who did not obey her mother's orders. Data collection was carried out in two stages. The first stage in this study was to inventory the data through literature study and recording oral literature from the folklore legends of the Minangkabau people in West Sumatra. The data submitted by the informants was recorded using a recording device. Then, the recorded data was transcribed into written form. The transcript was then translated from Minangkabau into Indonesian. The transliterated text of the story is studied and analyzed using morphological functional structure theory. The second stage in this research is to collect data about the storytelling environment, including the views and philosophy of life, as well as community values that tell the stories of local legends related to the oral literature of the Minangkabau folklore in West Sumatra. Data about the storytelling environment were collected through note-taking techniques, observation, and interviews.

\section{RESULTS AND DISCUSSION}

\subsection{Functional Structure}

The results of this reseach indicate that the folklore legends about Minangkabau girls in West Sumatra who disobeyed their mothers, from the aspect of their functional structures, can be formulated and grouped into twelve functions arranged in three situations, namely the initial situation, the transformation situation, and the last situation. In the initial situation there are four functions of the actors, namely (1) The initial situation: (a) living as an only child, (b) living only with the mother, (c) living in a very simple / poor situation, (d) lazy; (2) Transformation Situation: (e) likes to visit crowded places (including markets), (f) likes to decorate, (g) doesn't like to do routine household chores, (h) forces household chores on her mother; (3) Final situation: (i) going to the market with her mother, (j) not knowing her mother to anyone because her mother is poor, (k) being cursed by her mother. (L) becoming a stone because of the mother's curse.

The four folk tales that are the object of study in this study can be explained as follows. The legend of the Batu Puti Bayang folklore in the Early Situation, told in Nagari Api-api, Bayang District, Pesisir Regency, West Sumatra Province, in the Initial Situation, it is told (a) Puti, the name of a woman, her only child, (b) she lives only with her mother, not explained about his father, (c) very poor and simple life, (d) lazy but luxurious lifestyle; (2) Transformation Situation: (e) likes to visit crowded places (including market), (f) likes to dress up, (g) doesn't like doing housework, (h) forces household chores on his mother; (3) The last situation: (i) likes to argue with her mother and likes to ignore her mother's request to do any work, (j) the mother who feels very disappointed and can't stand Puti's behavior anymore, (k) Puti is cursed by her mother because her mother is a person parents feel abused; (l) while nodding in the sea at the seashore, Puti and Big Dipper turn into stones because of their mother's curse.

Second, the Legend of Awang Tingkuluak in Korong Buluah Kasok, Nagari Sungai Sariak, Tujuah Koto Sungai Sariak District, Padang Pariaman Regency, West Sumatra Province, in the Initial Situation it is told (a) a girl, without a name, is an only child, (b) is already has no father and only lives with her mother, (c) both of them live in poverty, (d) this daughter is a lazy person and likes to say harsh words. In the Transformation Situation, it is said that (e) the daughter is taken by her mother as her friend to look for firewood at the edge of the forest to sell, (f) comes home looking for firewood, the mother and child pass through the rice fields, (g) even though the mother has asked for help so that her child helps carry wood burning in a persuasive manner, this girl refused and did not want to help her mother, (h) she forced the work of transporting firewood on her mother, the mother was forced to carry all the firewood to hold; (3) Final Situation: (i) not only did not help her predicament, this girl even rebuked and cursed her mother, (j) her mother felt very disappointed and was 
very proud of her daughter's actions, (k) this girl accidentally slipped and fell into the swamp rice fields, and slowly sinking from the legs, waist, chest, and finally sinking his head into the paddy swamp; (l) the mother keeps trying to help her child out of the rice swamp but to no avail, the body of the child sinks into the swamp, only the tingkuluak (shawl) remains.

Third, the legend of Batu Manangih in Nagari Ngalau, Payakumbuh City, West Sumatra Province. Initial Situation, it is told (a) there is a family that only has daughters, (b) lives only with the mother, the father is not explained, (c) lives in very simple and sad conditions, (d) is lazy and likes to argue with the mother; (2) Transformation Situation: (e) likes to play and have fun, (f) doesn't like doing housework, (g) forces household chores on the mother; (3) Final Situation: (i) likes to argue with her mother and one day she ignores her mother's request to do any work, (j) her mother feels very disappointed and can't stand her child's behavior anymore and becomes sick, $(\mathrm{k})$ her mother's illness persists - late until finally his mother died; (1) this girl regretted her actions and kept on crying and retreating into the cave crying and somehow she became a stone in the cave, and the stone continues to shed water to this day.

Fourth, the legend of Batu Bangkai in Kanagarian Alam Pauah Duo, Pauah Duo District, Solok Selatan District, West Sumatra Province, in the Initial Situation, it is told (a) Dara, the name of a girl, her only child, (b) she lives only with her mother, not explained about his father, (c) he and his mother are not from a poor family but not too rich, (2) Transformation Situation: (e) Dara has entered adulthood, Dara went into exile, (f) after going through exile, Dara got married, (g) Not long after marriage, Dara became pregnant. (h) Dara's husband left Dara and her in-laws to migrate to find a better income and job; (3) The final condition: (i) after the husband left, the life of Dara and her mother became difficult and worrying, (j) one time during the rainy season their house was flooded because the roof was leaking, (k) Mrs. Dara asked her child to look for thatch leaves to repair the roof the house leaked, Dara did not want to help her mother, even scolded her mother, her mother felt very disappointed and sad for her daughter's behavior, then the mother cursed her child, (l) While walking on the rice field on a rainy day, Dara slipped, part of her body sank into in the rice fields, then his body became stone due to his mother's oath and curse.

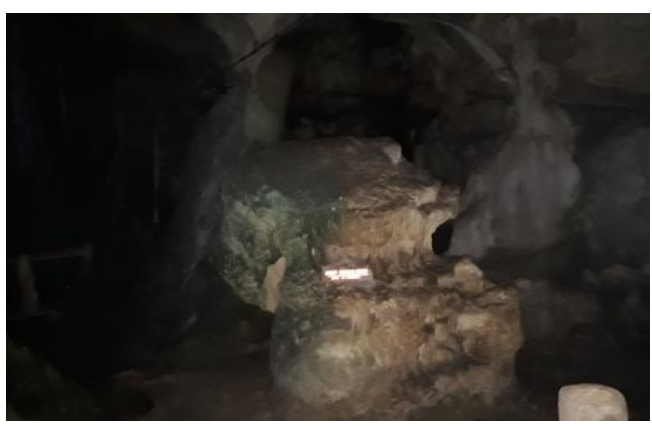

Figure 1. Crying Stone in Ngalau Indah Pakan Sinayan, West Payakumbuh sub-district, Payakumbuh City

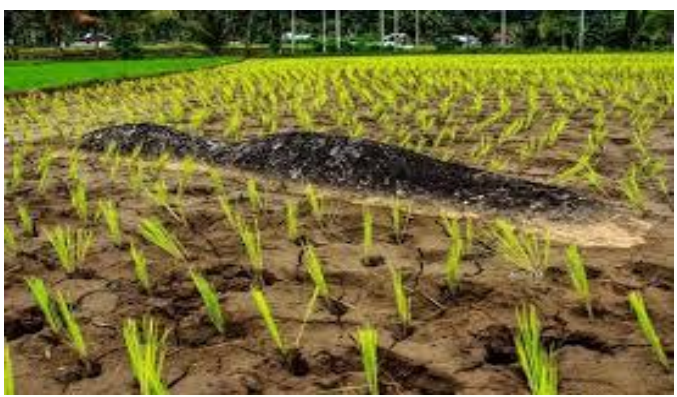

Figure 2. Batu Bangkai in Jorong Batu Bangkai Nagari Alam Pauah Duo

Table 1.

Functional Model of Legends of Folktale on Unruly Minangkabau's Daughter in West Sumatra

\begin{tabular}{|c|c|c|c|c|c|c|c|c|c|c|c|c|c|}
\hline \multirow[t]{3}{*}{ Num. } & \multirow{3}{*}{$\begin{array}{c}\text { Titles of the } \\
\text { Legends Folktale }\end{array}$} & \multicolumn{12}{|c|}{ Function of character } \\
\hline & & \multicolumn{4}{|c|}{ Initial situation } & \multicolumn{4}{|c|}{$\begin{array}{c}\text { Transformation } \\
\text { Situation }\end{array}$} & \multicolumn{4}{|c|}{ Final Situation } \\
\hline & & $\mathbf{a}$ & b & $\mathbf{c}$ & d & $\mathbf{e}$ & $\mathbf{f}$ & g & $\mathbf{h}$ & $\mathbf{i}$ & $\mathbf{j}$ & $\mathbf{k}$ & 1 \\
\hline 1. & Batu Puti Bayang & $\sqrt{ }$ & $\sqrt{ }$ & $\sqrt{ }$ & $\sqrt{ }$ & $\sqrt{ }$ & $\sqrt{ }$ & $\sqrt{ }$ & $\sqrt{ }$ & $\sqrt{ }$ & $\sqrt{ }$ & $\sqrt{ }$ & $\sqrt{ }$ \\
\hline 2. & Awang Tingkuluak & $\sqrt{ }$ & $\sqrt{ }$ & $\sqrt{ }$ & $\sqrt{ }$ & $\sqrt{ }$ & $\sqrt{ }$ & $\sqrt{ }$ & $\sqrt{ }$ & $\sqrt{ }$ & $\sqrt{ }$ & $\sqrt{ }$ & $\sqrt{ }$ \\
\hline 3. & Batu Manangih & $\sqrt{ }$ & $\sqrt{ }$ & $\sqrt{ }$ & $\sqrt{ }$ & $\sqrt{ }$ & $\sqrt{ }$ & $\sqrt{ }$ & $\sqrt{ }$ & $\sqrt{ }$ & $\sqrt{ }$ & $\sqrt{ }$ & $\sqrt{ }$ \\
\hline 4. & Batu Bangkai & $\sqrt{ }$ & $\sqrt{ }$ & $\sqrt{ }$ & $\sqrt{ }$ & $\sqrt{ }$ & $\sqrt{ }$ & $\sqrt{ }$ & $\sqrt{ }$ & $\sqrt{ }$ & $\sqrt{ }$ & $\sqrt{ }$ & $\sqrt{ }$ \\
\hline
\end{tabular}

Based on the results of this resrach, functionally the morphological structure of the local legends of the Minangkabau girl in West Sumatra who is disobedient to her mother from the coastal area and from the mainland of the West Sumatra region has the same and complete morphological form. Another thing that can be 
seen is the similarity of the four stories originating from coastal areas and land (mountains), it turns out that the main character has the same behavior, namely behaving disrespectfully and likes to say harshly to his mother.

\subsection{Actor Motives}

Research on folklore by Proop [3] and [4] Greimas [5], Dundes [9], Brunvand [6], Danandjaja [7], and Koentjaraningrat [8] has similarities and is consistent with local Minangkabau legends about children. disobedient woman. It is likely that the number of folklore legends in each culture is far greater than that of myths and fairy tales. Four folk tales of local legends about Minangkabau girls in West Sumatra who disobeyed their mothers as objects in this study came from two different areas, namely the coastal areas and the mainland of West Sumatra. There is a similarity in the aspect of the motive of the perpetrator and there is no difference in the aspect of the motive of the actor between the two different stories in this area. To find out how the general motif of local legends folklore about Minangkabau girls in West Sumatra who rebelled against their mothers. As seen in the following table.

Table 2.

The Similarities and Differences in the Motivation of Folk Stories of Local Legends of Minangkabau

\begin{tabular}{|c|c|c|c|c|}
\hline \multirow[t]{2}{*}{ No. } & \multicolumn{2}{|c|}{$\begin{array}{c}\text { The area of origin of the Legends } \\
\text { Folktale }\end{array}$} & \multicolumn{2}{|l|}{ Actor Motives } \\
\hline & Coastal & Mountains & Equation & Difference \\
\hline \multirow[t]{5}{*}{1.} & \multirow{5}{*}{$\begin{array}{lr}\text { Batu } & \text { Puti } \\
\text { Bayang and } \\
\text { Awang } \\
\text { Tingkuluak }\end{array}$} & \multirow{5}{*}{$\begin{array}{l}\text { Batu Manangih } \\
\text { and } \quad \text { Batu } \\
\text { Bangkai }\end{array}$} & Only child. She doesn't have another brother and sister & \\
\hline & & & Lives and is raised only by his mother (single parent) & \\
\hline & & & Came to live in poor because & \\
\hline & & & $\begin{array}{l}\text { Cursed by her mother for doing an act that displeases } \\
\text { her mother }\end{array}$ & \\
\hline & & & $\begin{array}{l}\text { All turned into stone. They do not just change to be } \\
\text { the stone, but stones which are partly or entirely } \\
\text { immersed in the sea, swamp, rice fields, or isolated } \\
\text { in the cave. }\end{array}$ & \\
\hline 2. & $\begin{array}{lr}\text { Batu } & \text { Puti } \\
\text { Bayang } & \text { and } \\
\text { Awang } & \\
\text { Tingkuluak } & \end{array}$ & $\begin{array}{l}\text { Batu Manangih } \\
\text { and } \quad \text { Batu } \\
\text { Bangkai }\end{array}$ & & $\begin{array}{l}\text { No } \\
\text { difference } \\
\text { found }\end{array}$ \\
\hline
\end{tabular}

\subsection{Functional Structure, Motives, and Themes}

The functional structure of the Minangkabau folklore about a girl who is disobedient to her mother forms the theme of the story. The theme as well as the main and important messages formed by the functional structure. Folklore listeners ask not to imitate the character of the storyteller, especially those related to the behavior and motives of the perpetrators of disobedience and persecution. The motives of the actors of dissent and criticism are not presented to be imitated. In connection with the research conducted by Greimas, this type of storytelling is known as the myth of freedom.

\section{CONCLUSION}

One of the intangible cultural heritages of the Minangkabau collective is folklore. There are several folk stories that are popular in Minangkabau, one of which is the folklore of a girl who disobeyed her mother. As an intangible cultural heritage, folklore has several social functions, including as a means of education, as a projection system; as a means of ratifying social institutions; and as a means of monitoring so that community norms are always adhered to and implemented by the local community. This legend also serves as a means of communication and social control to criticize someone or a group who has violated social norms. Criticizing someone using folk tales is more acceptable and more effective than outright. This is because folklore is not impersonal. As noted by Bakar [9], Siegel [10] and Sulistyowati [11]. 


\section{REFERENCES}

[1] Navis, A.A. 1984. Alam Terkembang Jadi Guru: Adat dan Kebudayaan Minangkabau. Jakarta: Grafiti Press

[2] Barthes, R. (2003). Mitologi (translate by Christian Ly). Bandung: Dian Aksara Press

[3] Proop, V. (1967). Morphology of the Folktales. Bloomington:Indiana University Press

[4] Greimas, AJ. (1972). "Comparative Mythtology" in Miranda P (Ed.). Mythology. P. 162-170. Harmondsworth: Penguin

[5] Dundes, A. (Ed.) 2005. Folklore: Critical Concept in Literary and Cultural Studies. Vol. I-III . London: Routledge

[6] Brunvand, J. H. (1973). "Book Review, Journal of American Folklore Vol. 86, p. 197-198" (in Folklor Indonesia by Danandjaja, 1984) Jakarta: Grafiti

[7] Danandjaja, J. (1984). Folklor Indonesia: Ilmu Gosip, Dongeng, Dan Lain-lain. Jakarta: Grafiti Press

[8] Koentjaraningrat. (2009). Ilmu Antropologi (Edisi Revisi). Jakarta: Rineka Cipta

[9]Bakar, J.dkk. (1981). Sastra Lisan Minangkabau. Jakarta: Pusat Pembinaan dan Pengembangan Bahasa

[10] Siegel, J. (1979). Shadow and Sound: The Historical Thought of a Sumatran People. Chicago: University of Chicago Press

[11] Sedyawati, E. (2007). Keindonesiaan dalam Budaya. Jakarta: Wedatama Widya Sastra

[12] Hasanuddin WS, Emidar, Zulfadhli. 2019. "Morphology of Legens Folktale of the Minangkabau Boys in West Sumatra Who Was Rebellious To His Mother" in International Conference on Language, Literature, and Education (ICLLE 2). Padang, August 22-23, 2019 